\title{
A COMPARATIVE DISCOURSE ON MEDIA PRACTICE IN COLONIAL AND POST-COLONIAL NIGERIA
}

\author{
Ibitayo S. Popoola (a), Tosin A. Adesile (b), Ibrahim O. Odenike (c) \\ (a) University of Lagos. Lagos, Nigeria. Email: tayonigeria[at]gmail.com \\ (b) Elizade University. Ilaramokin, Nigeria. Email: tosin.adesile[at]elizadeuniversity.edu.ng \\ (c) Lagos State Polytechnic. Lagos, Nigeria. Email: nomail[at]nomail.com
}

\begin{abstract}
This is a comparative study on media practice in colonial and post-colonial Nigeria. It covers journalism practice from 1920-2020. The study focuses on journalism practice during the days of nationalism-cum-political journalism era, led by Herbert Macaulay, Dr. Nnamdi Azikiwe, Chief Obafemi Awolowo, Chief Anthony Enahoro, Mr Ernest Seseilkoli, amongst others. The study adopts journalism during the colonial days, up to the time of independence in 1960, as foundation, and compares it to the modern day journalism practice at the moment. The thesis in the study is anchored on the probing question of establishing changes that have taken place in the profession over a period of 160 years. While providing fresh discussions on the current journalism practice as well as the daunting challenges facing media professionals in Nigeria today, the study provides groundbreaking recommendations to rescue journalism that is almost comatose in Nigeria today. The study uses free press theory as theoretical underpinning, and the key informants interview method.
\end{abstract}

\section{Keywords}

comparative discourse; political journalism; free press; media; Nigeria; post-colonialism

This work is licensed under a Creative Commons «Attribution» 4.0 International License. 


\section{СРАВНИТЕЛЬНЫЙ ДИСКУРС МЕДИАПРАКТИК В КОЛОНИАЛЬНОЙ И ПОСТКОЛОНИАЛЬНОЙ НИГЕРИИ}

\section{Попула Ибитайо С. (a), Адесиле Тосин А. (b), Оденике Ибрагим О. (c)}

(a) Университет Лагоса. Лагос, Нигерия. Email: tayonigeria[at]gmail.com

(b) Университет Элизад. Илара-Мокин, Нигерия. Email: tosin.adesile[at]elizadeuniversity.edu.ng

(c) Лагоский государственный политехнический. Лагос, Нигерия. nomail[at]nomail.com

\section{Аннотация}

Статья посвящена сравнительному анализу медийных практик в колониальной и постколониальной Нигерии. Исследование охватывает журналистскую практику 1920-2020 годов и фокусируется на журналистской практике во времена национал-политической журналистики, представленной в числе других Гербертом Маколеем, доктором Ннамди Азикиве, вождем Обафеми Аволово, вождем Энтони Энахоро, Эрнестом СесеиИколи.

Исследование берет за основу журналистику в колониальные времена, вплоть до обретения независимости в 1960 году и сравнивает ее с современной журналистской практикой.

В центре внимания находится вопрос анализа изменений, произошедших в профессии за 160-летний период. Предлагая свежее обсуждение современной журналистской практики, а также сложных проблем, с которыми сегодня сталкиваются работники СМИ в Нигерии, исследование дает принципиально новые рекомендации по спасению журналистики, находящейся сейчас в почти коматозном состоянии в Нигерии. В качестве теоретической основы в исследовании используется теория свободной прессы, а также метод интервью с ключевыми информаторами.

\section{Ключевые слова}

сравнительный дискурс; политическая журналистика; свободная пресса; медиа; Нигерия; постколониализм

Это произведение доступно по лицензии Creative Commons «Attribution» («Атрибуция») 4.0 Всемирная 


\section{INTRODUCTION}

Media historians, notably Omu (1996), Coker (1968), cited by Popoola (2019) and leading communication scholars in Nigeria- Opubor, Akinfeleye, Sobowale (1986) contend that regular printing and publishing of newspapers started in Nigeria in 1859 when the European missionary, Rev. Henry Townsend began the publication of a bi-lingual religious newspaper, Iwe-Irohin, in Abeokuta, South Western Nigeria, about 161 years ago.

This study focuses on Tador's (1996) second and third generations of the Nigerian press. Quoting Tador (1996), Wali (2003) classified the history of the Nigerian press into three broad categories, namely:

(i) The Early Press (1800-1920)

(ii) The Nationalist Press (1920-1960)

(iii) The Modern Nigerian Press (1960-date)

While the study uses the second phase above as the colonial foundation for the study, it uses the third phase as the post-independent phase of the study.

Journalistic activities of frontline nationalists, Herbert Macaulay, Dr, Akinwande Savage, Ernest Sesei Ikoli, Dr. Nnamdi Azikiwe, Chief Obafemi Awolowo, Chief Anthony Enahoro amongst others, were given special attention in the study. In the words of Akinfeleye (1990), these foremost journalists "did their work faithfully, fearlessly and selflessly in the best interest of the people".

\section{STATEMENT OF THE PROBLEM}

Journalism practice in Nigeria dates back to 1859 , a period of over 160 years. However, the myriad of problems facing the profession gives the impression that it's a young profession.

From the onset till date, journalism remains one profession in Nigeria with several constraints and challenges. From archival records, it was gathered that from the onset, media professionals received ridiculously low salaries. Some were not paid as at when due, leading to a situation where many of them never looked at their jobs as a career of a lifetime. To worsen matters, journalists at this point in time were further haunted by the fear of economic, as well as job insecurity.

It is pathetic that the gloomy picture of the profession, as painted by founding fathers of the profession, has not radically changed. This in- 
formed the objectives of this study, following which the research questions were drawn.

\section{OBJECTIVES OF THE STUDY}

(i) To examine the consistent problems militating against journalism after over 160 years of professional practice in Nigeria.

(ii) To identify urgent steps that must be taken in addressing problems militating against journalism after over 160 years of professional practice in Nigeria.

(iii) To recommend steps that must be taken to turn things around for journalism practice in Nigeria.

\section{RESEARCH QUESTIONS}

(i) What are the consistent problems militating against journalism in Nigeria after over 160 years of professional practice?

(ii) What are the urgent steps that must be taken in addressing problems militating against journalism after over 160 years of professional practice in Nigeria?

(iii) What are the necessary steps that must be taken to turn things around for journalism practice in Nigeria?

\section{METHODOLOGY}

This study is anchored on the ethnographic method in which the phenomenon for exploration is clearly defined with relevant questions in a bid to determine what media professionals, who are the objects of this study, identify as the consistent major problems facing media practice in Nigeria. Therefore, the study is conducted through purposive interviews which rely on Key Informants (KI) Method who have expert knowledge on the subject under examination.

\section{THEORETICAL FRAMEWORK}

This study is established based on the Libertation Theory of the press. Espousing the theory, Martin and Chaudhary (1983), cited in Popoola et al (2019), the press under the theory exist to uncover and present the truth to the people. Operationally, the press also operate as a private enterprise with little or no government control.

Martin and Chaudhary classified the media under the theory as "autonomous media". They explained that autonomous media make their 
own rules of operation, set their own goals and decide on their own interest.

Furthermore, they identified profit motive as the main goal of people venturing into media business. According to them, "publishing or broadcasting for profit, self-aggrandizement or out of altruism, is the principal activity of owners of autonomous media".

While stressing that most media in the Western Europe and some print media in developing countries are autonomous, Martins and Chaudhary (1983) argued that "in such countries, broadcast media are either privately owned or are controlled by a public corporation".

Blake and Haroldsen (1978) cited in Popoola et al (2019), on their part stated that the philosophy of the theory is rooted in the ideas of John Milton, John Locke, John Stuart Mill, Isaac Newton, Adam Smith and other philosophers that man has the right to pursue truth and that truth is best advanced when there is an "open market place of ideas". Expatiating on the concept of "open market of ideas", Grossberg et al (1998) say "the idea of a free marketplace of ideas assumes equivalence between the world of commerce and the world ideas: As products compete, ideas do too. In free competition, the good and useful drive out the bad and worthless. Thus, the driving spirit of liberal capitalism suggests that free people, left with their own initiative, will make economically and intellectually profitable choices".

Grossberg et al further observed that the First Amendment to the US Constitution which states that "Congress shall make no law abridging freedom of speech, or of the press...", was predicated upon this theory, arguing that "if government does not interfere in expression, the free marketplace will assure that good ideas will drive out bad ones, and truth will prevail".

\section{LITERATURE REVIEW}

From the onset, journalism remains one profession in Nigeria with several constraints and challenges. It would not be an exaggeration to say at the time it was founded, the foundation was erected upon challenges (Popoola, 2019, p. 66)

The above quotation is very apt in opening up the literature review segment of this study. A major problem that confronted journalism practice in Nigeria in the beginning was the problem of education and training.

Journalism practice began in 1859 . However, there was no training of any sort until 1954 when a two-week "vocation course in journalism" was conducted for working journalists at the premier university, the Univer- 
sity of Ibadan. In other words, journalism practice had existed for about 95 years before training commenced.

Akinfeleye (2011) in a special study on journalism education and training in Nigeria says "from 1962-1980, there were only two universities in Nigeria that offered formal journalism/mass communication training in Nigeria". He listed the universities as University of Nigeria, Nsukka and the University of Lagos, Akoka, Yaba.

At the time of putting this report together, there are 66 universities in Nigeria, including the newly established Department of Mass Communication at both Landmark University, Omu-Aran and Trinity University, Yaba, Lagos and 41 polytechnics offering Mass Communication and Media Studies/Journalism in Nigeria.

Akinfeleye (2011) however offered explanations for the late takeoff of journalism education and training in Nigeria. He contends that this could be traced to one of the conclusions of Colins Sparks of the Communication Faculty of the Polytechnic of Central London who concluded that:

Journalism in the United Kingdom is not a profession. In a number of countries, the status of "professionalism" is legislatively defined, but in the United Kingdom's(former colonial rulers of Nigeria) sociological tradition, the term "profession" is restricted to those occupations which meet certain tightly defined criteria, and journalism is not yet part of them in the UK. (Akinfeleye, 2011, pp. 3940)

It could therefore be deduced from the above, that the nearly-100year occupation of Nigeria by Great Britain contributed in no small measure to the problems of journalism in Nigeria.

The trend has however changed today as could be seen from the list of over 100 institutions offering journalism and mass communication training in Nigeria today. Many university graduates from other academic disciplines such as Political Science, Sociology, Economics, Geography, History, Philosophy, etc, are now crossing over to journalism (Mass Communication).

In the area of journalists' welfare, conditions from the colonial past till date are not only perplexing, but also worrisome.

Popoola (2019) says from archival records, it was learnt that, at this point in history (colonial days), media professionals received ridiculously low salaries, and some were not even paid as at when due, leading to a situation where many of them never looked at their jobs as a career of a lifetime. To worsen matters, journalists at this point in time were further haunted by the fears of economic and job insecurity. 
The above precarious situation has not really changed. Chairman of the Lagos State Council of Nigerian Union of Journalists (NUJ), Dr. QuasimAkinreti, was quoted by Freedom Online, an online newspaper, saying a number of media proprietors have failed woefully to pay salaries of members as at when due. He listed the culprits as Champion, Vanguard, ThisDay newspapers and Daar Communications, the owners of RayPower100.5 FM, Faaji FM and AIT.

Idowu (2018) blamed the above problem on what he called the parlous economy, that has seen progressive devaluation in the national currency between 2000 and 2015, which has also constrained the economic power of the media with dire consequences. Quoting Olukotun (2015), Idowu declared:

For the media, between 1999 and 2016, many titles like The Sketch, Concord, Post Express, Anchor, Tempo, National Interest, The Comet, New Age, Spectator Weekly, Westerner, Newswatch, Next New Nigerian, Nigerian Compass and PM News/The News, have disappeared from the newsstands. (Idowu, 2018, p. 105)

Idowu further contends that where the media are not free and strong enough to discharge their expected responsibilities to the society, it is a matter of time before that influence begins to be eroded.

Reflecting on the Nigerian media in the Fourth Republic, Idowu says:

They have resorted to all sorts of schemes to keep afloat in the stormy sea of publishing with unpleasant consequences for the media's ability to carry out investigative reporting on which depends such concerns as transparency, accountability and good governance.(Idowu, 2018, p. 105)

Article 7(i) of the Code of Ethics for Nigerian Journalists forbids a journalist to neither solicit nor accept bribe, gratification or patronage to suppress or publish information.

However, Idowu (2018) contends that "many journalists see nothing wrong in accepting money to publish stories. He cited the example of a midnight parley between former military president, General Ibrahim Babangida (Rtd.) with about 40 journalists at his country home in Minna. He said Babangida was then positioning himself for another shot at the presidency, this time through the ballot box:

His publicists had arranged this midnight parley with senior journalists, including editors, to learn firsthand of Babangida's planned return to office. An online news medium, Sahara Reporters, reported that Babangida had not only gathered such a large crowd of journalists to his Minna home at that strange hour, but each journalist went home with $\mathrm{N} 250,000(\$ 1666)$ as transport reimbursement. (Idowu, 2018, p. 111) 
Popoola (2018) similarly identified unfriendly environments, within which the media are operating, as another critical issue. He noted that coping with state and news sources' anger remains a major problem for media professionals in colonial and post-colonial Nigeria. While noting that publishing false news is a criminal offence, Popoola observed that when a truthful story is published, such a story might earn the writer a jail term:

When Ray Ekpu wrote an article that warned authorities of the Nigerian External Telecommunications Ltd. (NET) to guard their installations, in the wake of rising fraud-induced cases of arson in the country, his advice was ignored. How ever, when the NET building was torched a day after the publication of the article and two people died in the inferno, Ekpu was arrested and charged for murder. (Popoola, 2019, p. 90)

Mention could also be made of in the imprisonment of the duo of Nduka Irabor and Tunde Thompson of the Guardian newspaper for publishing an article which government felt was an embarrassment. They were jailed one year each while the Guardian newspaper was fined N50,000.

\section{DATA PRESENTATION AND ANALYSIS}

The population for this study are the 12 regular newspapers, 39 radio stations and 13 television stations operating in Lagos as identified by Idowu (2018).

From this population, the study extracted a sample size of 10 newspapers, 20 radio stations and 10 television stations. The figures represent $83 \%, 51 \%$ and $77 \%$ respectively of newspapers, radio and television stations operating in Lagos. From the newspapers, radio and TV, two respondents who are senior journalists were purposively selected for Key Informant Interview (KII). In all, a total of 100 respondents were involved in the study. Data from the respondents were subsequently analysed qualitatively to enable its outcome to be understood, digested and invariably used in tackling the research questions. While analysing the data, different issues were treated under appropriate research questions as hereby presented.

RQ1: What are the consistent problems militating against journalism in Nigeria after 160 years of professional practice?

A good number of the respondents to this study (97\%) identified poor remuneration or not being paid as of when due as a consistent problem facing the profession. 
They were of the view that as it was during the days of Dr, Nnamdi Azikwe, Chief Obafemi Awolowo, Chief Anthony Enahoro and Mr Ernest Sesei Ikoli, when journalists were poorly remunerated and a laughing stock in the community, the trend has not really changed significantly.

The Sports Editor of Murhi International TV, James Segbowe, said, "Journalists are not being respected as they should. They are similarly not being accorded their rightful place in the society."

The study also found out that some journalists still go to assignments without enough transportation fares while many others go home at the end of every month with half or no salary.

The respondents similarly argued that even though there are many more opportunities these days unlike during the colonial era, the profession remains unprofitable, frustrating and soul depressing.

The Head of News Department in one of the TV stations, who pleaded anonymity, said one of the ethical principles of journalism is that journalists must not collect brown envelope but added that "as of today and even in times past, poorly-paid journalists are more likely to participate in the collection of brown envelope."

The Manager, News and Current Affairs of a privately-owned radio station expressed a similar view. He pointed out that most privatelyowned media houses still owed salaries and allowances of up to one year. He revealed that some government owned media are similarly defaulting.

It was a tale of woe as the media professionals lamented that as welfare of staff constituted a major problem to journalism practice in colonial Nigeria, the trend still remained daunting in the post-independent era.

Providing the picture of journalism practice in the beginning during colonial Nigeria, Popoola (2019) said journalists in the beginning were poorly paid, some were not paid as of when due, while an atmosphere of job insecurity pervaded the industry. Many of the media professionals in this study said the situation has not really changed.

Chairman of the Lagos State Council of the Nigeria Union of Journalists (NUJ), Dr Quasim Akinreti, said some media owners had failed woefully to pay salaries as of when due.

He identified The Champion, Vanguard, ThisDay Newspapers and Daar Communications, owners of AIT, Raypower 100.5FM and Faaji FM as major culprits.

His words: Champion owes journalists in his stable over 64 months of salaries and emoluments. The Vanguard could not pay salaries for about six months now. ThisDay newspaper, with huge profits made by the company and expansion to other areas of the media, could not pay salaries regularly until when accumulated for months. Even the government- 
owned Radio Lagos/Eko FM and Lagos Television are part of the defaulters for failing to pay retirement benefits of members who retired from these stations after serving the state meritoriously".

The respondents further claimed that COVID-19 brought irreparable damage to media practice in Nigeria, with several media houses, like The Nation, Punch, amongst others, sacking hundreds of media professionals.

Elsewhere, Platform Africa, reports that 128 print newspapers across the world reportedly shut down, while thousands of journalists were fired in 24 hours.

Top of the reasons identified by the three percent of the respondents who treated the question centered on the state of the Nigerian economy. They argued that the foreign exchange has not been stable and often times on the increase with its adverse effects on either raw materials or production equipment. They further contend that some radio stations have international sponsors and this has helped such stations to be ahead of other stations.

RQ2: What are the urgent steps that must be taken in addressing problems militating against journalism, after over 160 years of professional practice in Nigeria?

A number of suggestions were made by the respondents to address the various problems confronting media practice in Nigeria. Top of the suggestions are:

I. Journalism should not be an all-comer's affairs. Media owners should be restricted to media professionals, just as it is done for other professions in Nigeria, especially Medicine, Law and Engineering.

II. Government and the regulatory bodies should set a minimum deposit henceforth for any aspiring media proprietors as done for the insurance and banking sectors while infiltration of unserious-minded Nigerians coming into the industry should be prohibited.

III. The existing curriculum for journalism training should be reviewed so as to accommodate more practical that are more relevant to the development of the society.

IV. The students should revamp themselves by letting their contents and work speak for them.

V. Media houses should drop the garment of being government puppets or megaphones and serve public interest. 
VI. Media proprietors should invest more in their employees by putting them on regular training to improve their skills and proficiency.

VII. Ethical uprightness and adherence to the various rules of engagement, especially media law.

VIII. Journalism being the sixth most stressful job in the world according to CareerCast, a job search engine, requires an attractive welfare package that should be embraced by all media proprietors in Nigeria.

RQ3: What are the necessary steps that must be taken to turn things around for journalism practice in Nigeria?

To turn things around, majority of the respondents $70 \%$ suggested the need for corporate bodies and wealthy individuals to float a bail out scheme for distressed journalists. They contend that if such bailout fund could be raised in the wake of the outbreak of COVID-19 in Nigeria, nothing stops such measures to be taken in a bid to rescue journalism by tackling wretchedness and poverty.

They similarly suggested that the media could individually follow the example of Dr. Nnamdi Azikwe, who launched an appeal for financial aid from his supporters and friends when his West African Pilot was facing official victimization and was financially distressed.

It was further suggested the need to improve on the contents of what the media are dishing out to the public, in order not to allow social media relegate them to the background. At the moment, Idowu (2018), says news media are fond of presenting sponsored special section stories as news features. According to him "this amounts to non-full disclosure and shortchanges the audience".

They similarly tasked the professional bodies, the Guild of Editors and the NUJ to work towards enthroning journalists' independence of action, especially in the area of choice of news sources and news selection.

They canvassed the need to change the terrible perception of the first generation of Nigerian journalists, whose perception was captured by Chief Obafemi Awolowo, who remarked that "people took to journalism because there was no good job elsewhere". The respondents said as at today, majority of practicing journalists in Nigeria, see the profession as a stepping stone to other things.

It was further suggested the need to dismantle "journalism of meal ticket" and restore the profession to the respected practice of news hunting without ulterior motives. 
Majority of the respondents further see the major problem confronting the profession as ethically related.

They contend that many journalists behave on the field as if they have little grounding in the ethics of journalism. Idowu (2018) alluded to this assertion.

He contends that some journalists do not know they are not expected to collect gratifications from news sources. His words: "Some see it as perks of the office and are acculturated by despicable seniors to see it so. They grow up with a false sense of entitlement with great injury to their individual sense of worth and the soul of the profession".

The respondents further revealed absence of orientation programme to sensitize journalists on the need to pursue their assignments with dedication and sufficient knowledge.

\section{DISCUSSION, SUMMARY AND RECOMMENDATIONS}

Journalism in Nigeria has come of age. It remains one of the oldest professions in the country. The painful narrative about journalism in Nigeria is that in spite of the over a century and half existence of journalism in Nigeria, the challenges facing the profession make it look as if it came into existence yesterday.

This study established that practice preceded training as the first newspaper was established in 1859 while the first training took place in 1954, a period of 95 years. Therefore, training was a major problem. Even though 66 universities and 46 polytechnics are currently offering various programmes in Journalism and Mass Communication, this study established that training still remains a major problem.

To address the problem, the National Universities Commission (NUC) approved the unbundling of Mass Communication to seven fields, namely: Journalism and Media Studies, Public Relations, Advertising, Broadcasting, Film and Multimedia studies, Development Communication, Information and Media Studies. This is a step in the right direction that would go a long way in finding solutions to the problem of inadequate training.

As it was during the colonial days, when according to Chief Obafemi Awolowo, "nothing critical must be written about the Nigerian Government or expatriate officials in spite of the fact that things were happening, which aroused the just resentment and indignation of young Nigerians", the trend has only changed a bit today.

Popoola (2019) says "Nigeria continues to rank high among countries where press freedom and freedom of expression are under threat." 
The political journalism of the colonial era laid the foundation of passion for news hunting. They were described by Idowu (2018) as "foot soldiers". Many of them trekked a long distance during the colonial day to places of assignment.

Chief Awolowo recalled: "Only editors and their immediate assistants could afford to own a bicycle". However, this day, in spite of the hardship facing the profession, many journalists ride state-of-the-art vehicles.

Journalism welfare is non-existent, going by the ridiculous and depressing salary of Nigerian Journalists.

Nkereuwen (2012) says the salary of Nigerian Journalists range from between $\mathrm{N} 20,000$ and N40,000 (\$124-\$247). He stressed that one or two pay about N70,000 (\$432). He described them as the high flyers, adding that "it is, therefore, conclusive that more than 80 per cent of the journalists in the country do not earn enough to pay their basic bills."

Oshunkeye (2011) provides the implication of such ridiculous salary:

As long as we continue paying journalists slave wages, as long as media owners continue to pay wages that hardly take journalists home, so long would the roots of corruption in the industry deepen. So long would mediocrity continue to thrive in the industry and so long would the consuming public continue to doubt products that the media churn out day after day.

\section{RECAP AND RECOMMENDATIONS}

The study examined journalism practice in colonial and post-colonial Nigeria. It established that many of the problems facing journalism practice in Nigeria today dates back to the colonial days. In spite of the over 160 years of unbroken practice, the problems are yet to subside.

The study put forward three RQs in the beginning.

RQ1 asked: What are the consistent problems militating against journalism after 160 years of professional practice in Nigeria?

The respondents to the study identified the problems as inadequate training, poor remuneration, irregular payment of salaries, non-payment of retirement benefits, hostile environment, and rampaging effect of COVID-19, which has forced several media houses to sack hundreds of workers amongst others.

RQ2 asked: What are the urgent steps that must be taken in addressing problems militating against journalism practice after over 160 years of professional practice in Nigeria?

The respondents provided an 8-point suggestion to the question. 
RQ3 asked: What are the necessary steps that must be taken to turn things around for journalism practice in Nigeria?

Majority of the respondents (70\%) suggested the need for wealthy Nigerians and corporate bodies to float a bail out scheme similar to the one put in place in the wake of the COVID-19 outbreak.

They further suggested an appeal fund similar to that of Dr. Nnamdi Azikwe when he was facing financial hardship in the running of the West African Pilot as a result of government hostilities during the colonial days.

\section{RECOMMENDATIONS} dations:

Based on the above, the study put forward the following recommen-

1. Need to amend Section 39(2) of the Nigerian 1999 Constitution, which states that "every person shall be entitled to own, establish and operate any medium for the dissemination of information, ideas and opinions." This clause is the major problem facing journalism practice in Nigeria. Journalism shouldn't be an all comers affair.

2. Government and the regulatory bodies, such as the Nigerian Press Council (NPC) and the National Broadcasting Commission (NBC), should set a minimum deposit for media proprietors just as it's done for the insurance and banking sectors.

3. Urgent implementation of the NUC Policy of unbundling of Mass Communication.

4. Need for an attractive welfare package for journalists because of the delicate and stressful nature of the profession.

References

Akinfeleye, R. A. (1986). Religious Publications: Pioneers of Nigerian Journalism. In Onuora \& Onwuneli (Eds.). Mass Communication in Nigeria: A Book of Reading. Enugu: Fourth Dimension Publishing Co. Ltd.

Akinfeleye, R. A. (1990). Journalism in Nigeria: A Profession or a Craft. In R.A. Akinfeleye (Ed.), Media Nigeria: Dialectic Issues in Nigerian fournalism. Lagos: Nelson Publishers Ltd.

Akinfeleye, R. A. (2011). Essentials of Journalism: An Introductory Text. Lagos: Malthouse. Mass Communication Books.

Awolowo, O. (1960). The Autobiography of Chief Obafemi Awolowo. London: Cambridge University Press.

Azikiwe, N. (1970). My Odyssey: An Autobiography. New York: Praeger. 
Blake, R. H. \& Haroldsen, E. O. (1975). A Taxonomy of Concepts in Communication. New York: Hastings House Publishers.

Coker, I. H. E. (1968). Landmarks of the Nigerian Press. Lagos: Nigerian National Press Ltd.

Constitution of the Federal Republic of Nigeria (1999). Lagos: Federal Government Press

Grossberg, L., Wartella, E. \& Whitney, D.C. (1998). Media Making: Mass Media in A Popular Culture. New Delhi: SAGE Publications

Idowu, L. (2018). Corruption in the Nigerian Media: The Brown Envelope Syndrome. In Ayo Olukotun (Ed.). Watchdogs or Captured Media: A Study of the Role of the Media in Nigeria's Emergent Democracy 1999-2016. Lagos: Diamond Publications Ltd.

Martin, L .J. \& Chaudhary, A. G. (1983). Comparative Mass Media Systems. New York: Longman Inc.

Muhammad-Wali, A. (2003). Press Freedom and National Security: A Study in the Dynamics of Journalists and Security Agents Relationship in Nigeria. Zaria: Open Press Ltd.

Nkereuven, E. (2012). Nigerian Journalists and Brown Envelope. Sahara Reporters. Retrieved from https://saharareporters.com

Omu, F. I. A. (1996). Journalism in Nigeria: Historical Overview. In Olatunji Dare \& Adidi Uyo (Eds.), Journalism in Nigeria: Issues and Perspectives. Lagos: Nigeria Union of Journalists, Lagos State Council.

Onyekwelu, S. (2020). Seven Courses Emerge from NUC's Unbundling of Mass Communication Degree. Business Day. Retrieved from:

https://businessday.ng/education/article/seven-courses-emerge-from-nucsunbundling-of-mass-communication-degree/

Osunkeye, S. (2011). Journalism vs Brown Envelope. Paper presented at the Media Project Regional Conference, Accra, Ghana.

Platformafrica (2020). Retrieved from https://platformafrica.com

Popoola, I. (2019). Parrot fournalism: A Professional Guide in Investigative fournalism. Lagos: Diamonds Publications.

Popoola, I., Ajibade, O., \& Obia, V. (2019). Ethical Dimension of Newspaper Management and Production: an Inquiry into the Failed Evening Newspapers in Lagos, Nigeria. Galactica Media: Journal of Media Studies, 1(2), 43-61. Doi: 10.24411/2658-7734-2019-10 012

Tador, M. (1996). History of the Press. In Tony Momoh (Ed.). The Press in Nigeria. Abuja: Nigerian Press Council.

Список литературы

Akinfeleye, R. A. (1986). Religious Publications: Pioneers of Nigerian Journalism. In Onuora \& Onwuneli (Eds.). Mass Communication in Nigeria: A Book of Reading. Enugu: Fourth Dimension Publishing Co. Ltd. 
Akinfeleye, R. A. (1990). Journalism in Nigeria: A Profession or a Craft. In R.A. Akinfeleye (Ed.), Media Nigeria: Dialectic Issues in Nigerian fournalism. Lagos: Nelson Publishers Ltd.

Akinfeleye, R. A. (2011). Essentials of Journalism: An Introductory Text. Lagos: Malthouse. Mass Communication Books.

Awolowo, O. (1960). The Autobiography of Chief Obafemi Awolowo. London: Cambridge University Press.

Azikiwe, N. (1970). My Odyssey: An Autobiography. New York: Praeger.

Blake, R. H. \& Haroldsen, E. O. (1975). A Taxonomy of Concepts in Communication. New York: Hastings House Publishers.

Coker, I. H. E. (1968). Landmarks of the Nigerian Press. Lagos: Nigerian National Press Ltd.

Constitution of the Federal Republic of Nigeria (1999). Lagos: Federal Government Press

Grossberg, L., Wartella, E. \& Whitney, D.C. (1998). Media Making: Mass Media in A Popular Culture. New Delhi: SAGE Publications

Idowu, L. (2018). Corruption in the Nigerian Media: The Brown Envelope Syndrome. In Ayo Olukotun (Ed.). Watchdogs or Captured Media: A Study of the Role of the Media in Nigeria's Emergent Democracy 1999-2016. Lagos: Diamond Publications Ltd.

Martin, L .J. \& Chaudhary, A. G. (1983). Comparative Mass Media Systems. New York: Longman Inc.

Muhammad-Wali, A. (2003). Press Freedom and National Security: A Study in the Dynamics of Journalists and Security Agents Relationship in Nigeria. Zaria: Open Press Ltd.

Nkereuven, E. (2012). Nigerian Journalists and Brown Envelope. Sahara Reporters. Retrieved from https://saharareporters.com

Omu, F. I. A. (1996). Journalism in Nigeria: Historical Overview. In Olatunji Dare \& Adidi Uyo (Eds.), Journalism in Nigeria: Issues and Perspectives. Lagos: Nigeria Union of Journalists, Lagos State Council.

Onyekwelu, S. (2020). Seven Courses Emerge from NUC's Unbundling of Mass Communication Degree. Business Day. Retrieved from:

https://businessday.ng/education/article/seven-courses-emerge-from-nucsunbundling-of-mass-communication-degree/

Osunkeye, S. (2011). Journalism vs Brown Envelope. Paper presented at the Media Project Regional Conference, Accra, Ghana.

Platformafrica (2020). Retrieved from https://platformafrica.com

Popoola, I. (2019). Parrot fournalism: A Professional Guide in Investigative fournalism. Lagos: Diamonds Publications.

Popoola, I., Ajibade, O., \& Obia, V. (2019). Ethical Dimension of Newspaper Management and Production: an Inquiry into the Failed Evening Newspapers in Lagos, 
Galactica Media: Journal of Media Studies. 2020. No 2 | ISSN: 2658-7734

Subaltern Studies and Media | Doi: 10.46539/gmd.v2i2.104

Nigeria. Galactica Media: Journal of Media Studies, 1(2), 43-61. Doi: 10.24411/2658-7734-2019-10 012

Tador, M. (1996). History of the Press. In Tony Momoh (Ed.). The Press in Nigeria. Abuja: Nigerian Press Council. 